\begin{tabular}{lcr}
\hline & ANNALES \\
& UNIVERSITATIS MARIAE CURIE-SKLODOWSKA & \\
LUBLIN - POLONIA & \\
VOL. VI & SECTIO M & 2021 \\
\hline
\end{tabular}

\author{
Agnieszka Wicha \\ Cardinal Stefan Wyszyński University in Warsaw, Poland \\ agnieszka.wicha@onet.pl \\ ORCID: https://orcid.org/0000-0002-6499-3393
}

\title{
Non-financial disclosures requirements as a regulation model for promoting and imposing sustainable finance within the European Union
}

\section{Introductory remarks}

In this paper, the author intends to analyze the role of non-financial disclosures in achieving the goals established in the European Green Deal (EGD). The topic of sustainable finance and the regulation of this area in European Union (EU) is very developmental and would affect the future shape of the EU economy and that of particular member states and enterprises. The legislative activities in the EU are innovative and unprecedented; there are no previous events or legal solutions that could be compared to the current legislative activities of the EU in this field. To understand the regulatory impact assessment, the author researched selected legislative initiatives launched since 2018 to 2021 in the area of sustainable finance. In doing so, she scrutinized current and planned non-financial disclosures requirements and their impact on the achievement of goals established in the European Green Deal (EGD). The research was based on the interpretation of the aims presented in the EGD and of regulations in the area of sustainable finance. The interpretation is supplemented by regulatory impact assessment.

The hypothesis set is that strengthening and broadening the legal obligations in reference to non-financial disclosures aims to impel enterprises to produce 
and work in more sustainable ways, to achieve sustainable development goals and to develop sustainable finance. The pressure would not be created by setting some thresholds for private enterprise when it comes to the environmental goals, but by their obligation to show to the public how their activity impact on sustainable development goals. Therefore, the research question is whether the newly established and proposed disclosure requirements will force undertakings to consider their impact on sustainable developments goals or not.

The author used a legal-dogmatic method. In the scope of the analysis there were acts of the European Union law in force, but also acts in development and European Commission non-binding documents. It needs to be underlined that these legislative activities are closely connected with the political goals and political interest of the member states of the European Union, therefore, the analysed topic does not only concern the legal aspects, but also the political meaning and the political implications of those actions. Hence, the author used a decision-making method based on political science as well.

Currently, sustainable topics and challenges are one of the most important topics discussed within the EU. Climate change and the destruction of the natural environment are important global issues, and the problem has been discussed among the international community for several years. As a result, national governments, international organisations and non-government organisations have launched actions towards broad protection of the environment and of human rights. The United Nations (UN) has played a crucial role by inspiring and animating cooperation in the area ${ }^{1}$.

Sustainable development goals (SDG) are on the list of seventeen most important goals that should be achieved by 2030 to protect the environment and to guarantee prosperity for the whole of humanity. Those seventeen goals were the fundamental part of the 2030 Agenda for Sustainable Development. The document is the resolution of the General Assembly from 25 October, 2015, and defines the greatest challenges for humanity. This resolution does not concern environmental topics alone, but also social challenges ${ }^{2}$.

The holistic and comprehensive approach presented by the UN should be considered the key for the future development and protection of the planet. SDG lays-out the general aims which should determined the activities of every member states and the UN as a whole. The tools chosen by countries and international organizations to fulfill these aims could, however, vary.

1 The webpage of the United Nations, https://sdgs.un.org/goals, “THE 17 GOALS”, access 13 XI 2021.

2 A/RES/70/1, Resolution adopted by the General Assembly on 25 September 2015. 
One of the biggest problems the world is facing is the increasing global average temperature. The impact of human activity on global warming has been confirmed. The Intergovernmental Panel on Climate Change (IPCC) prepared for political decision-makers has published several reports with periodic assessment of the situation of climate change and the human impact on it. Such reports include projections and forecasts ${ }^{3}$. The last report published by the IPCC was published on $7^{\text {th }}$ August, 2021. This once again underlined the harmful impact of human activity on the natural environment ${ }^{4}$. In this regard, the most important document from the perspective of the recent years was the Paris Agreement. This is the international treaty adopted in 2015 in Paris, during the Conference of Parties to the United Nations Framework Convention on Climate Change. This global agreement was signed by the European Union and its member states, ${ }^{5}$ as well as by most nation members of the United Nations. The main goal of the Paris Agreement is to reduce the emission of greenhouse gasses and to stop and even roll back the increases in global average temperature ${ }^{6}$.

European Green Deal as a general EU strategy towards sustainable development

The EU is an active actor in sustainability. The competences of the EU in the context of sustainable development are not, however, fully transparent because the term "sustainable development" encompasses a variety of topics and policies. First of all, it needs to be underlined that the term has been used in EU primary law. Under art. 3 Treaty on European Union (TUE), where the aims of the EU were established, the term "sustainable development" is employed in the context of internal market. The place and the context of using the term imply the role of it as a general principle of the EU. Still, there is discussion on this topic. No matter the conclusion from the debate on the place of sustainable development in

3 The Webpage of the IPCC, https://www.ipcc.ch/, "Synthesis Report of the Sixth Assessment Report", access 13 XI 2021.

4 IPCC, "Summary for Policymakers. In: Climate Change 2021: The Physical Science Basis. Contribution of Working Group I to the Sixth Assessment Report of the Intergovernmental Panel on Climate Change", 2021, Cambridge University Press. In Press, p. 6.

5 OJ L 103, 19.4.2016, "Council Decision (EU) 2016/590 of 11 April 2016 on the signing, on behalf of the European Union, of the Paris Agreement adopted under the United Nations Framework Convention on Climate Change", p. 1-2.

6 OJ L 282, 19.10.2016, “Paris Agreement", p. 4-18, article 2. 
EU primary law, however, there are examples of secondary law where the term "sustainable" or the aim of "sustainable development" is addressed".

Taking into account the general aim of the EU - "to promote peace, its values and the well-being of its peoples" (art. 3.1 TUE), it seems to be crucial to understand the idea of sustainable development and to connect it with challenges generated by climate changes and to protect the EU economy from the negative impact of the destruction of the environment. That is why sustainable development is one of the priorities of the European Commission.

The European Green Deal (EGD) was unveiled by the European Commission on $11^{\text {th }}$ December, $2019^{8}$. It needs to be underlined that this communication and activity was not the first step made by the EU into the direction of sustainability. In 1973, The EU announced the Environmental Action Programme - which was the beginning of many EU initiatives and actions for the environment and sustainable development ${ }^{9}$. It should be noted that environmental issues are the foundation of sustainability and one of the biggest challenges of current society.

The EGD was basically a communication from the European Commission (EC) to other European Union institutions. It is not a binding legal act of the European Union, but it is a significant source of information about the strategy (both political and legislative) of the EC. As stated by T. Biernat, communications are one of the possible sui generis normative non-binding acts of the EU institutions. Communications from the EC should, therefore, be treated as a type of soft $l a w^{10}$. Moreover, communications should be considered as the form of presentation of the position of the EC towards particular issues or policies ${ }^{11}$. The EGD is, thus, the presentation of the idea and the approach of the EC to achieve the sustainable developments goals and commitments agreed to by the EU under the Paris Agreement. This communication could be also seen as the

7 J. Jendrośka, M. Reese and L. Squintani, Towards a new legal framework for sustainability under the European Green Deal, "Opolskie Studia Administracyjono-Prawne”,2021, no 19 (2), p. 92-94.

8 COM/2019/640 final, "Communication from the Commission to the European Parliament, The European Council, The Council, The European Economic And Social Committee And The Committee of The Regions. The European Green Deal".

9 D. Claringbould, M. Koch, P. Owen, Sustainable Finance: The European Union's Approach to Increasing Sustainable Investments and Growth-Opportunities and Challenges, "Vierteljahrshefte zur Wirtschaftsforschung", 2019, Vol. 88, Iss. 2, p. 12.

10 T. Biernat, Soft law a proces tworzenia prawa w Unii Europejskiej. Wptyw soft law na konstrukcję i treść uzasadnień aktów normatywnych, „Studia Prawnicze. Rozprawy i Materiały”, 2012, nr 2 (11), p. 31.

${ }^{11}$ K. J. Gruszczyński, Administracyjny charakter aktów prawnych Komisji Europejskiej, „Zeszyt Naukowy, Wyższa Szkoła Bezpieczeństwa Publicznego i Indywidualnego "APEIRON" w Krakowie", 2009, nr 3, p. 41-42. 
long-term strategy of the $\mathrm{EU}^{12}$, and embraces not only the strategy on sustainable issues and environment protection, but also the strategy of economic and social transformation of the $\mathrm{EU}^{13}$.

In the European Green Deal, the EC defined the tools that would be used to achieve climate neutrality till 2050 . The ambitious goals dedicated to environment protection found in it put the EU in the position of global leader in this endeavor. This is a comprehensive plan that includes increasing the 'green' awareness of EU citizens, as well as changing industrial activity (specifically, 'greening' the production of steel, chemicals or cement, and agricultural practices).

These ambiguous aims require the input of a lot of capital. Apart from public funds, it will be necessary to involve private funds. Therefore, the financial sector has been given a special role ${ }^{14}$. Indeed, private investment is considered the key to sustainable development within the EU. Hence, the European Commission saw the need for a change in EU law to give long-term inducements for these investments ${ }^{15}$.

In the annex to the EGD, the EC presented an action plan with the list of the most important issues to be addressed, including legislative initiatives. One is the review of the Non-Financial Reporting Directive ${ }^{16}$, which is the core of the presented analysis. The realisation of the EGD will have a significant impact on the European Single Market and on the role of the EU in the international community and relations ${ }^{17}$.

The EGD is a comprehensive presentation of the UE goals in the field of sustainable development, and is an action plan for the upcoming years. Still, it is not the full presentation of the EU activities in this field. The EU is an actor at the global level (e.g. by being a part of the Paris Agreement), but is also engaged in internal EU initiatives. It needs to be underlined that before the publication of the EGD, there were other EU activities in this field. The most significant were

${ }_{12}$ M. Sobolewski, Europejski Zielony Ład - w strone neutralności klimatycznej, „INFOS Zagadnienia społeczno-gospodarcze”, 2020, nr 9 (275), p. 2.

${ }^{13} \mathrm{COM} / 2019 / 640$ final, "Communication from the Commission to the European Parliament, The European Council, The Council, The European Economic And Social Committee And The Committee Of The Regions. The European Green Deal", p. 2.

${ }^{14}$ Ibid., p. 8-20.

15 A. Pomykała, J. Raczyński, Europejski Zielony Ład dla Unii Europejskiej i jej mieszkańców, „TTS Technika Transportu Szynowego”, 2020, no. 12, p. 8.

${ }^{16} \mathrm{COM} / 2019 / 640$ final, "Communication from the Commission to the European Parliament, The European Council, The Council, The European Economic And Social Committee And The Committee Of The Regions. The European Green Deal", Annex, p. 4.

${ }_{17}$ H. Lee-Makiyama, The EU Green Deal and Its Industrial and Political Significance, "Policy Brief ECIPE”, 2021, no 1, p. 2-3. 
legislative initiatives aimed at creating the EU Emission Trading System ${ }^{18}$. In this context, the European Emission Trading System under directive 2003/87/EC ${ }^{19}$ should be pointed out. This is one of the most important initiatives aimed at reducing greenhouse gas emission. Currently, there are three important legislative measures in the scope of sustainable development: regulation 2020/852 ${ }^{20}$ (Taxonomy), regulation 2019/2088 ${ }^{21}$ (SFDR) and regulation 2019/208922. All these legislative initiatives were launched by the EC before the publication of the EGD, but the aims of these regulations are closely connected with the intentions of the EGD because they created a legal basis for developing and creating sustainable finance and sustainable investments.

\section{Financial institutions in the architecture of the EU sustainable development}

According to the EC, financial institutions are to play a crucial role in the transition of the entire EU economy into a more sustainable direction. The change of the way of working of the whole industry, services and mentality of EU citizens required huge investments, not only public but also private. Therefore, engagement of financial institutions is necessary. Sustainable finance is one of the core elements of the EC strategy expressed in the EGD. The EC has defined the term "sustainable finance" as the process of taking into consideration ESG ${ }^{23}$ factors during investment decision-making and in the process of increasing the awareness of investors with regard to ESG risks. Sustainable finance is, therefore, the tool to facilitate and create additional money for transitioning the current EU economy into a more sustainable, climate neutral and circular economy ${ }^{24}$.

${ }_{18}$ D. Claringbould, M. Koch, P. Owen, op. cit., p. 20-21.

19 OJ L 275, 25.10.2003, Directive 2003/87/EC of the European Parliament a-nd of the Council of 13 October 2003 establishing a scheme for greenhouse gas emission allowance trading within the Community and amending Council Directive 96/61/EC, p. 32-46.

20 OJ L 198, 22.6.2020, Regulation (EU) 2020/852 of the European Parliament and of the Council of 18 June 2020 on the establishment of a framework to facilitate sustainable investment, and amending Regulation (EU) 2019/2088, p. 13-43.

${ }^{21}$ OJ L 317, 9.12.2019, Regulation (EU) 2019/2088 of the European Parliament and of the Council of 27 November 2019 on sustainability-related disclosures in the financial services sector, p. $1-16$.

${ }_{22}$ OJ L 317, 9.12.2019, Regulation (EU) 2019/2089 of the European Parliament and of the Council of 27 November 2019 amending Regulation (EU) 2016/1011 as regards EU Climate Transition Benchmarks, EU Paris-aligned Benchmarks and sustainability-related disclosures for benchmarks, p. 17-27.

${ }^{23}$ ESG- environmental, social and corporate governance.

${ }_{24}$ Webpage of the European Commission, https://ec.europa.eu, "Overview of sustainable finance", access 16 XI 2021. 
In a more general meaning, sustainable finance is about the relation between lending and investing money and ESG goals. In this context, one can say that financial institutions are generators and suppliers of money and expertise knowledge that can be used in the processes of changing current practices into more environmental friendly activities and transitioning into more sustainable working ${ }^{25}$. The financial sector, hence, is not only intended to supply money, it is to facilitate the flow of money and to enhance informed investment decision making with the market ${ }^{26}$.

At the EU level, the role of the financial institutions was elaborated upon and was defined by a High-Level Expert Group on Sustainable Finance (HLEG). HLEG was established in December 2016, by the EC, as a part of the Capital Market Union initiative ${ }^{27}$. It consisted of experienced specialists drawn from various groups of stakeholders. The main aim of HLEG was to prepare recommendations for the EC regarding the directing of the flow of capital into sustainable development goals and the including of ESG risk into the activity of financial institutions ${ }^{28}$. In 2018, HLEG presented its final report. Among the recommendations was an idea to create a European green taxonomy - a system of classification of activities and investments with positive impact on sustainability goals. This taxonomy would also allow assessing whether the investment is or is not sustainable ${ }^{29}$.

The general recommendation that can be drawn from the report of the HLEG is to impose additional duties on financial institutions to provide disclosures of ESG-related issues and long-term investment strategy planning ${ }^{30}$. The idea of sustainable finance, hence, is to generate and strengthen the capital flow into achieving ESG goals and to change the general approach to investments. Accordingly, investors should not only think about and assess the financial return from the investment, but also about the impact of it on the sustainable goals put forth in the ESG and help to steer society into being a green society and to protect the environment ${ }^{31}$. Therefore, the intent is to change the preferences and expectations of investors through financial institution activities.

25 D. Schoenmaker, W. Schramade, Principles of Sustainable Finance, Oxford University Press, 2019, p. 4.

${ }^{26}$ Ibid., p. 18-19.

${ }^{27}$ Capital Market Union is the name of the general aim of the European Commission in building a single capital market within EU. This would be achieved by various legislative and non-legislative tools at the EU level. This is a process in progress.

${ }_{28}$ The Webpage of the European Commission, https://ec.europa.eu, "High-Level Expert Group on sustainable finance", access 13 XI 2021.

${ }^{29}$ Final Report 2018 by the High-Level Expert Group on Sustainable Finance, p. 15-18.

${ }^{30}$ Ibid., p. 20-25.

${ }^{31}$ D. Claringbould, M. Koch; P. Owen. op. cit., p. 16-18. 
The European infrastructure of sustainable finance should be considered in the context of three main regulations: Taxonomy, SFDR and changed regulation $2016 / 1011^{32}$. SFDR imposed additional disclosure requirements for financial market participants. These disclosures will be a source of information for investors on ESG risks and their potential impact on the return from the investment, and information on the impact of the investment on sustainability factors (how the investment influences ESG factors). The regulation the SFDR introduced to EU law provides definitions of "sustainable risks", "sustainability factors" and "sustainable investments" and creates a new part of the financial market regulation dedicated to sustainable development goals ${ }^{33}$. The introduced taxonomy establishes legal frameworks to assess which activities are environmentally sustainable. Thus, it puts in place criteria to classify investments as being environmentally sustainable. Hence, only investment in economic activity that contributes to achieving at least one environmental goal defined in the regulation 2020/852 and that complies with the established screening criteria and is in the line with defined minimum safeguards and is without any significant harm to the set-out environmental objectives can be named as an environmentally sustainable investment.

The EU Taxonomy creates a unique system of classification that is to be used by the financial market participants when offering and creating financial products. However, the Taxonomy only provides general rules and criteria, detailed and technical criteria will be given by the EC and supported by the Platform on Sustainable Finance ${ }^{34}$. For the purpose of building a sustainable financial market and sustainable instruments changes were introduced into regulation 2016/1011 by creating additional types of benchmarks. These are: "EU Climate Transition Benchmark" and "EU Paris-aligned Benchmark".

The main obligations implied by the abovementioned are being continuously supplemented by other requirements. On 21 April 2021, the EC presented the Sustainable Finance Package, which included several amendments to MIFID II, UCITS, AIFMD and Directive 2016/97 so as to incorporate sustainable factors into the current activities of financial institutions. Moreover, this package

32 OJ L 171, 29.6.2016, Regulation (EU) 2016/1011 of the European Parliament and of the Council of 8 June 2016 on indices used as benchmarks in financial instruments and financial contracts or to measure the performance of investment funds and amending Directives 2008/48/ EC and 2014/17/EU and Regulation (EU) No 596/2014, p. 1-65.

${ }^{33}$ J. Jendrośka, M. Reese and L. Squintani, op. cit., p. 97.

${ }^{34}$ The Webpage of the European Commission, https://ec.europa.eu, "Platform on Sustainable Finance", access 14 XI 2021. 
incorporated the Corporate Sustainability Reporting Directive ${ }^{35}$, and work on the management and disclosure of ESG risk in credit institutions and investment firm activity ${ }^{36}$. The EC is also working on the project of the European Green Bond Standard that would be directly connected with the EU Taxonomy ${ }^{37}$.

This is an incomplete listing of all legislative and non-legislative initiatives of the EC, yet it demonstrates the pressure imposed on financial institutions, as well as the crucial role of financial institutions in the whole sustainable architecture within EU. The amount of new regulations and imposed obligation could be overwhelming for the financial institutions, especially if one takes into consideration the fact that there is little experience and expertise knowledge in those sustainable topics and obligations. Therefore, there is a huge challenge before the financial institutions in implementing and endorsing all of the impositions. Taking into account the specificity of the activity of the financial institutions, the new requirements imposed on them will be transposed to the clients of those institutions, both as additional information for the clients and as the additional questions or requirements for the clients that are set out by these financial institutions.

\section{Current non-financial disclosures requirements and proposed changes}

When one thinks about the reporting obligation of the company, one mainly thinks about the financial information and financial statements of the company. This information is needed in assessing and understanding the financial condition of the company, especially when one is an investor or a stakeholder or if one considers investing in the particular company. Beyond the financial value of the company, there is also the nonmaterial value of the company. The need for identifying the full context of the operating of the company is the basis for establishing new requirements for companies to disclose non-financial information ${ }^{38}$.

${ }_{35}$ The Webpage of the European Commission, https://ec.europa.eu, "Sustainable finance package", access 15 XI 2021.

${ }^{36} \mathrm{EBA} / \mathrm{REP} / 2021 / 18$, EBA Report on management and supervision of ESG risks for credit institutions and investment firms.

${ }_{37} \mathrm{COM} / 2021 / 391$ final, Proposal for a Regulation of the European Parliament and of the Council on European Green Bonds.

${ }^{38}$ J. Fijałkowska, J. Krasodomska M. Macuda, and others, Sprawozdawczość niefinansowa. Regulacja $i$ standaryzacja raportowania niefinansowego przedsiębiorstw, Wydawnictwo Naukowe Uniwersytetu Szczecińskiego, 2019, p. 13-16. 
At the EU level, these non-financial disclosure requirements were established by directive 2014/95/EU ${ }^{39}$. This directive introduces changes in the directive 2013/34/EU and enlarges the scope of the content of the obligatory content of the annual financial statements.

To understand the context of the new proposals of the EC and to see the change of the direction into sustainability, one needs to see the current legal standing. Under the current version of directive 2013/34/EU, public interest entities (only those with at least 500 employees) should incorporate into their annual management statements, additional information about non-financial issues. Art. 19a and 29a lists this information. This list of five types of information is on a high level of generality with the general directive to disclose information important to understand the approach of the company to social, environmental, employment, governance, human rights and anticorruption issues. Companies need to disclose the information on the adopted business model, approved policies in this area, the results of the policies, identified main risks in this area and key performance indicators (KPI) defined by the company. This general directive left the space for every company to choose the way of presenting this information. Moreover, the legal form of the directive gave leeway in the opportunity to implement the imposed requirements into the domestic legal system. Therefore, one can say that directive 2013/34/ $\mathrm{EU}$ as it stood created frameworks for non-financial disclosures without the detailed standards and patterns for those disclosures.

Companies, thus, sought out patterns and forms for these disclosures. A common standard was delivered by Global Reporting Initiatives. However, local standards were also developed, e.g. in Poland, the SIN standard ${ }^{40}$. These standards were not obligatory, there was also a possibility for the company to choose individual models and methodologies of non-financial disclosures. This flexibility in the choice caused the risk of noncomparability of disclosed information between companies. This was brought to the attention of the EC, and thus some additional explanation as to how to disclose ESG information was therefore, delivered.

39 OJ L 330, 15.11.2014, Directive 2014/95/EU of the European Parliament and of the Council of 22 October 2014 amending Directive 2013/34/EU as regards disclosure of non-financial and diversity information by certain large undertakings and groups, p. 1-9.

${ }^{40}$ P. Ogrodnik, Standardy stosowane $w$ raportowaniu niefinansowym przez polskie spótki $z$ sektora odzież $i$ obuwie, notowane na rynku podstawowym Giełdy Papierów Wartościowych $w$ Warszawie, „Studia i Prace. Kolegium Zarządzania i Finansów. Zeszyty Naukowe”, 2019, no. 173, p. 63-64. 
In 2017, EC published guidelines on methodology for non-financial disclosures $^{41}$. In 2019, EC supplemented this document by guidelines on climate-related disclosures ${ }^{42}$. Still, the disclosed information was not comparable and there was a need to improve the requirements to guarantee the achievement of the set goals ${ }^{43}$.

Taking into account the need for standardisation and the better quality of disclosure of non-financial information and also the quest of sustainable development, on 21 April 2021, the EC spresented the Project of the changes in directive 2013/34/ EU, called the "Corporate Sustainability Reporting Directive" (CSRD) ${ }^{44}$. This change was dedicated to improving the standards of non-financial information delivered by companies. It is focused on two core issues: to broaden the scope of companies obliged to disclose non-financial information and to broaden the content of nonfinancial reports with more detailed ESG risk information. According to the EC, currently, only 11600 companies are obliged to published non-financial reports and after changes, approximately 49000 companies will have these obligations ${ }^{45}$. Broadening the amount of companies obliged to publish non-financial reports allows promoting awareness of the impact of company activity regarding ESG issues. The public availability of this information, in turn, allows assessing the social and environmental-related activity of the company. Moreover, it creates a wider availability of data for investors, public institutions and financial institutions.

The scope of the required information in non-financial reports also contributes to achieving the goals established in the European Green Deal. The general assumption is to ensure the usefulness of non-financial reports in fulfilling the obligations arising from SFDR and achieving coherence between non-financial reports and disclosures under Taxonomy ${ }^{46}$. The new proposal of content of nonfinancial reports includes (beside that currently disclosed) detailed information about the ESG risks and plans of the company towards contributing to mitigating climate transition (decreasing the global temperature). In addition, a company

${ }^{41}$ OJ C 215, 5.7.2017, Communication from the Commission - Guidelines on non-financial reporting (methodology for reporting non-financial information), C/2017/4234, p. 1-20.

${ }^{42}$ OJ C 209, 20.6.2019, Communication from the Commission - Guidelines on non-financial reporting: Supplement on reporting climate-related information, C/2019/4490, p. 1-30.

${ }^{43}$ E. Chojnacka, A. Bering, Struktura ramowa raportu zintegrowanego - wytyczne a praktyka wybranych przedsiębiorstw, „Studia i Prace. Kolegium Zarządzania i Finansów. Zeszyty Naukowe", 2018, no 160, p. 74-75.

${ }_{44}$ The Webpage of the European Commission, https://ec.europa.eu, "Sustainable finance package", access 8 XII 2021.

${ }^{45}$ COM/2021/189 final, Proposal for a Directive of the European Parliament and of the Council amending Directive 2013/34/EU, Directive 2004/109/EC, Directive 2006/43/EC and Regulation (EU) No 537/2014, as regards corporate sustainability reporting, p. 3-6, 13.

${ }^{46}$ Deloitte Report: Corporate Sustainability Reporting Directive. The Future Landscape of Sustainability Reporting. p. 3 
needs to present KPIs connected with those goals. Finally, the information published by the companies would not be presented in just any form, because, according to proposed art 19b, the European Financial Reporting Advisory Group (EFRAG) will put forth a detailed pattern for non-financial reports that will allow comparison of the non-financial reports of different companies.

The role of the financial institutions in the whole architecture of sustainable development of the $\mathrm{EU}$ is generated by the special role of the financial institutions in the economy. They deliver capital for every-day undertakings and activities in the economy. Therefore, engaging the financial institutions in the process of transition is the key to successful mitigation of climate change and generating sustainability. Financial institutions, such as banks, investment firms or insurance companies have got a special type of bond with the clients, and their main activities are connected with delivering money and securing risk. That is why the connections between financial institutions and non-financial undertakings would have a significant impact on the efficiency of the transition into sustainability. Understanding these connections is one of the most difficult challenges in bringing about sustainable finance. Taking into account this unique connection between financial and non-financial undertakings, one needs to see why financial institutions need to analyze the non-financial reports of their clients. If those reports are comparable, the way of their use financial institutions would be more automatic.

The link between Taxonomy and non-financial reports is particularly evident in art. 8 Taxonomy. This article obliges companies that publish non-financial reports to attach to them detailed information about the connection between the activity of the company and environmentally sustainable activities. The form and the granularity of this information is described by the EC in the delegated act to the art. 8 of Taxonomy ${ }^{47}$. Herein, the EC presented a particular KPI to enable financial and non-financial companies to understand the relation between sustainable development goals and the activities of the companies and the source of financing the process of transition.

Summing up, companies already have to or will have to in the near future disclose information about ESG factors, their approach to environmental challenges and the impact of the company upon these ESG goals. The stipulation to show publicly this information will impose greater transparency to this issue,

47 OJ L 442, 9.12.2021, Commission Delegated Regulation (EU) 2021/2139 of 4 June 2021 supplementing Regulation (EU) 2020/852 of the European Parliament and of the Council by establishing the technical screening criteria for determining the conditions under which an economic activity qualifies as contributing substantially to climate change mitigation or climate change adaptation and for determining whether that economic activity causes no significant harm to any of the other environmental objectives (Text with EEA relevance) p. 1-349. 
and enable comparability of data and accountability. Investors would, therefore, have a better opportunity to assess the company and if their money would contribute or not to achieving sustainable developments goals. Moreover, non-financial reports will allow creating sustainable finance by giving a better tool for financial companies to include the information in their activities, e.g. including ESG risk and informing clients on impact on the investment on sustainable development goals. The general idea of imposing the common disclosure of ESG information by companies seems to be very useful in the context of sustainable finance. However, there is one important problem that must be addressed. CSRD is only a project and according to the EC information, the first non-financial reports under new rules will be published in $2024^{48}$. This means that the financial institutions have already some new obligations under sustainable finance regulations, but the most basic and crucial information that is to be published in non-financial reports will not be available till 2024..

Since legislative activities made by the EC in the sustainable area allows achieving the political goals established in the European Green Deal, bearing in the mind the abovementioned identified scope of regulations, the aim of the regulations, the assessed outcome and the connections with sustainable finance, the author believes that the new disclosures regulations will change the way of thinking by the management of companies operating in the EU. The regulatory requirements will compel them to include ESG factors into the various aspects of their operating financial and non-financial undertakings. Moreover, the ESG factors will be more important in investment decisions, in the plans of the companies and the daily basis activities of the undertakings. In addition, taking into account the fact that the abovementioned information will be available publicly, the companies will treat it as a part of the factors affecting the company's image and brand. The potential impact assessment thus proves the correctness of the stated hypothesis governing this paper.

An ongoing and in-depth analysis of the regulatory impact assessment is recommended, as it is not possible to fully assess the effects of the regulation at such an early stage in the implementation and enforcement of new legislation. It is also uncertain whether the assumed goals will be achieved by the adopted regulations. It remains unknown whether the provisions in the area of sustainable finance will be redundant and too burdensome for some enterprises, therefore,

${ }^{48}$ The Webpage of European Capital Markets Institute, https://www.ecmi.eu, "Proposal for a Corporate Sustainability Reporting Directive" - Presentation of the European Commission available on the Webpage, access 10 XII 2021. 
it is necessary to examine the periodic impact of the regulations and to identify barriers to the development of enterprises and the capital market.

\section{Bibliography}

\section{Sources}

- Commission Delegated Regulation (EU) 2021/2139 of 4 June 2021 supplementing Regulation (EU) 2020/852 of the European Parliament and of the Council by establishing the technical screening criteria for determining the conditions under which an economic activity qualifies as contributing substantially to climate change mitigation or climate change adaptation and for determining whether that economic activity causes no significant harm to any of the other environmental objectives, OJ L 442, 9.12.2021

- Communication from the Commission - Guidelines on non-financial reporting (methodology for reporting non-financial information), C/2017/4234, OJ C 215, 5.7.2017, p. 1-20.

- Communication from the Commission - Guidelines on non-financial reporting: Supplement on reporting climate-related information, C/2019/4490, OJ C 209, 20.6.2019, p. 1-30.

- Communication from the Commission to the European Parliament, The European Council, The Council, The European Economic And Social Committee And The Committee Of The Regions. The European Green Deal, COM/2019/640 final.

- Council Decision (EU) 2016/590 of 11 April 2016 on the signing, on behalf of the European Union, of the Paris Agreement adopted under the United Nations Framework Convention on Climate Change, OJ L 103, 19.4.2016, p. 1-2.

- Directive 2003/87/EC of the European Parliament a-nd of the Council of 13 October 2003 establishing a scheme for greenhouse gas emission allowance trading within the Community and amending Council Directive 96/61/EC, OJ L 275, 25.10.2003, p. 32-46.

- Directive 2014/95/EU of the European Parliament and of the Council of 22 October 2014 amending Directive 2013/34/EU as regards disclosure of non-financial and diversity information by certain large undertakings and groups, OJ L 330, 15.11.2014, p. 1-9.

- Paris Agreement, OJ L 282, 19.10.2016, p. 4-18.

- Proposal for a Regulation of the European Parliament and of the Council on European Green Bonds, COM/2021/391 final.

- Proposal for a Directive of the European Parliament and of the Council amending Directive 2013/34/EU, Directive 2004/109/EC, Directive 2006/43/EC and Regulation (EU) No 537/2014, as regards corporate sustainability reporting, COM/2021/189 final

- Regulation (EU) 2016/1011 of the European Parliament and of the Council of 8 June 2016 on indices used as benchmarks in financial instruments and financial contracts or to measure the performance of investment funds and amending Directives 2008/48/ EC and 2014/17/EU and Regulation (EU) No 596/2014,OJ L 171, 29.6.2016, p. 1-65.

- Regulation (EU) 2019/2088 of the European Parliament and of the Council of 27 November 2019 on sustainability related disclosures in the financial services sector, OJ L 317, 9.12.2019, p. 1-16.

- Regulation (EU) 2019/2089 of the European Parliament and of the Council of 27 November 2019 amending Regulation (EU) 2016/1011 as regards EU Climate Transition 
Benchmarks, EU Paris-aligned Benchmarks and sustainability-related disclosures for benchmarks, OJ L 317, 9.12.2019, p. 17-27.

- Regulation (EU) 2020/852 of the European Parliament and of the Council of 18 June 2020 on the establishment of a framework to facilitate sustainable investment, and amending Regulation (EU) 2019/2088, OJ L 198, 22.6.2020, p. 13-43.

- Resolution adopted by the General Assembly on 25 September 2015, A/RES/70/1.

\section{Literature}

- Biernat T., Soft law a proces tworzenia prawa w Unii Europejskiej. Wptyw soft law na konstrukcję i treść uzasadnień aktów normatywnych, „Studia Prawnicze. Rozprawy i Materiały", 2012, nr 2 (11).

- Chojnacka E., Bering A., Struktura ramowa raportu zintegrowanego - wytyczne a praktyka wybranych przedsiębiorstw, „Studia i Prace. Kolegium Zarządzania i Finansów. Zeszyty Naukowe", 2018, nr 160, p. 74-75.

- Claringbould D., Koch M., Owen P. , Sustainable Finance: The European Union's Approach to Increasing Sustainable Investments and Growth - Opportunities and Challenges, "Vierteljahrshefte zur Wirtschaftsforschung", 2019, Vol. 88, Iss. 2.

- Fijałkowska J., Krasodomska J., Macuda M., i in., Sprawozdawczość niefinansowa. Regulacja i standaryzacja raportowania niefinansowego przedsiębiorstw, Szczecin, 2019, p. 13-16.

- Gruszczyński K. J., Administracyjny charakter aktów prawnych Komisji Europejskiej, „Zeszyt Naukowy”, Wyższa Szkoła Bezpieczeństwa Publicznego i Indywidualnego "APEIRON" w Krakowie, 2009, no. 3.

- Jendrośka J., Reese M. and Squintani L., Towards a new legal framework for sustainability under the European Green Deal, "Opolskie Studia Administracyjono-Prawne", 2021, no 19 (2).

- Lee-Makiyama H., The EU Green Deal and Its Industrial and Political Significance, "Policy Brief ECIPE", 2021, nr 1.

- Ogrodnik P. , Standardy stosowane w raportowaniu niefinansowym przez polskie spótki z sektora odzież i obuwie, notowane na rynku podstawowym Giełdy Papierów Wartościowych w Warszawie, „Studia i Prace. Kolegium Zarządzania i Finansów. Zeszyty Naukowe”, 2019, nr 173, p. 63-64.

- Pomykała A., Raczyński J., Europejski Zielony Ład dla Unii Europejskiej i jej mieszkańców, „TTS Technika Transportu Szynowego”, 2020, nr 12.

- Sobolewski M., Europejski Zielony Ład - w stronę neutralności klimatycznej, „INFOS Zagadnienia społeczno-gospodarcze”, 2020, nr 9 (275).

- Schoenmaker D., Schramade W., Principles of Sustainable Finance, Oxford, 2019.

\section{Internet sources}

- The Webpage of European Capital Markets Institute, https://www.ecmi.eu, "Proposal for a Corporate Sustainability Reporting Directive" - Presentation of the European Commission available on the Webpage.

- The Webpage of the European Commission, https://ec.europa.eu, "Overview of sustainable finance". 
- The Webpage of the European Commission, https://ec.europa.eu, „High-Level Expert Group on sustainable finance".

- The Webpage of the European Commission, https://ec.europa.eu, "Platform on Sustainable Finance".

- The Webpage of the European Commission, https://ec.europa.eu, "Sustainable finance package".

- The Webpage of the IPCC, https://www.ipcc.ch/, "Synthesis Report of the Sixth Assessment Report".

- The Webpage of the United Nations, https://sdgs.un.org/goals, "THE 17 GOALS”.

\section{Reports}

- Final Report by the High-Level Expert Group on Sustainable Finance, 2018.

- EBA Report on management and supervision of ESG risks for credit institutions and investment firms, EBA/REP/2021/18, 2021.

- IPCC, "Summary for Policymakers. In: Climate Change 2021: The Physical Science Basis. Contribution of Working Group I to the Sixth Assessment Report of the Intergovernmental Panel on Climate Change", Cambridge University Press. In Press, 2021.

- Deloitte Report "Corporate Sustainability Reporting Directive. The Future Landscape of Sustainability Reporting", 2021.

Summary: The Author has the intent of analysing the role of non-financial disclosure in achieving goals established in the European Green Deal (EGD). The article, therefore, presents the aims set out in the EGD and the regulations created within the European Union (EU) in the area of sustainable finance. The Author will also define sustainable finance. In the last part of the Article, the author will present the current state and proposed changes in the rules of non-financial reporting. Finally, the Article will inform the reader of the connection between non-financial reports and sustainable finance and usability of CSRD (Corporate Sustainability Reporting Directive) in the architecture of sustainable finance.

Key words: sustainable finance, CSRD, EU Green Deal, non-financial reports

Wymogi ujawnień niefinansowych jako model regulacyjny w celu promocji i wdrożenia zrównoważonego finansowania w Unii Europejskiej

Streszczenie: Zbadano rolę ujawnień informacji niefinansowych w osiąganiu celów określonych w Europejskim Zielonym Ładzie. W artykule przedstawiono idee określone w unijnym Zielonym Ładzie i przeanalizowano powstające regulacje w obszarze zrównoważonych finansów. Wyjaśniono definicję zrównoważonych finansów, poddano analizie proponowaną zmianę zasad raportowania niefinansowego. W artykule przedstawiono związek między raportami niefinansowymi a zrównoważonymi finansami i użytecznością CSRD w architekturze zrównoważonych finansów.

Słowa klucze: zrównoważone finanse, CSRD, Europejski Zielony Lad, raporty niefinansowe 